\title{
Aglaenita Spinola and $A$. bipunctata Spinola (Hemiptera, Auchenorrhyncha, Cicadellidae): redescription of both taxa and taxonomic notes ${ }^{1}$
}

\author{
Rodney Ramiro Cavichioli ${ }^{2}$
}

\begin{abstract}
Aglaenita Spinola and A. bipunctata Spinola are redescribed; the geographic distribution of the species is widened to Brazil (Mato Grosso). The taxonomic position of Aglaenita is also altered, now considered as belonging to Neocoelidiinae. The correct spelling of the generic name is discussed.

KEY WORDS. Auchenorrhyncha, Cicadellidae, Neocoelidiinae, Aglaenita
\end{abstract}

In the literature the genus name is spelled in two different ways: Aglaenita and Aglenita. SPINOLA (1850) published two papers, in sequence: in the first "Tavola sinottica...", he described the genus as Aglaenita, and in the second, "Di alguni generi...", he redescribed the genus and added a new species, $A$. bipunctata. This time, however, the name of the genus was spelled Aglenita. Subsequent authors (OMAN et al. 1990) regarded it as a case to be solved by action of the First Reviser. As MetCALF (1966) used Aglenita, OMAN et al. (1990) considered him as being the First Reviser, accepting the spelling Aglenita as valid since then. Therefore, other authors as EVANS (1947) used Aglenita. SCHUlzE et al. (1926) and NEAVE (1939) (apud MeTCALF 1966) used Aglenita and Aglaenita as error.

According to the Article 32, a-b, of I.C.Z.N., the "original spelling" of a name is the spelling used in the work in which it was first established; and the "correct original spelling" must be preserved unaltered. So, the work of Spinola in which the name Aglaenita was established is "Tavola sinottica..." and not "Si alguni generi..." that followed. Therefore, the spelling to be preserved is Aglaenita.

The taxonomic position of the genus Aglaenita was uncertain until now; some considered as Idiocerinae, others as Cicadellinae and Evans (1947) as uncertain position. The examination of a sintype (female) from Spinola's collection, together with other specimens from Mato Grosso (Brazil) showed that it belongs to Neocoelidiinae. All the characters examined matched with those referred by OMAN (1949), to Neocoelidiinae as: "clypellus subquadrangular, clypeal suture slightly arched; clypeus elongate; lateral sutures extending to or near eyes; distance between ocelli equal to distance between antennal pits; ocellocular area produced in a distinct oblique ledge above antennal pit".

1) Contribuição número 767 do Departamento de Zoologia, Universidade Federal do Paraná.

2) Departamento de Zoologia, Universidade Federal do Paraná. Caixa Postal 19020, 81531-990 Curitiba, Paraná, Brasil. Bolsista CNPq.

E-mail: cavich@bio.ufpr.br 


\section{Aglaenita Spinola, 1850}

Aglaenita Spinola, 1850: 59. - Young, 1977: 286.

Aglenita [sic] Spinola, 1850: 132. - Schulze et al., 1926: 84. -Neave, 1939: 90. - Evans, 1947: 251. Metcalf, 1966: 233. - Oman et al., 1990: 286.

Type-species: Aglenita [sic] bipunctata Spinola, 1850: 132, by original designation.

Redescription. Head triangular in dorsal view, median length of crown $4 / 7$ to $3 / 5$ of transocular width and $2 / 3$ of interocular width; anterior margin angulate with a strong carina in the transition between crown and face (front); ocelli located in the anterior margin, close to carina, near to eyes; dorsal surface flat; antennal ledges not prominent in dorsal view, strongly oblique and carinate in lateral view; front [sensu MEJDALANI (1998)] longer than its basal width, profile slightly angulate basally, muscle impressions undistinct; front-clipeal suture complete, slightly arched; clypeus continuous to profile contour front but with apical portion strongly curved. Pronotal width greather than head, medium length $3 / 8$ of the width between the humerus; lateral margins anteriorly convergent, posterior margin concave, dorsal surface with grooves in the posterior third; notopleural carina complete; basally, scutellum as wide as long. Forewing $31 / 2$ times longer than largest width; venation distinct with elevated veins, with four apical cells, base of the fourth cell more proximal than third, without an plexus of veins and cross veins; with closed outer anteapical cell. Posterior wings almost as long as forewings and with complete $\mathrm{R} 1+2$.

Pygofer of the male basally wide with strong medium narrowing in direction to ventral margin, forming a projection longer than the basal width. Plate subgenital almost as long as the length of the pigofer, more rectangular in shape. Styles long, slender. Connective almost half the length of styles, "inverted - V" shaped, with slender branches. Aedeagus long, wide from base to the middle, tapering from the middle to apex, dorsally curved and turning back to the base.

Female. Pygofer long of triangular shape. VII sternite more rectangular, posterior margin truncate with a shallow median concavity.

Comments. Aglaenita Spinola, 1850 is close to Coelana DeLong, 1953 and to Coelidiana Oman, 1938, regarding to the shape of male genitalia, especially the aedeagus. The pygofer of the male, on the other hand, is quite different presenting a projection longer than the basal width, finishing bifid or not. YouNG (1977) supposedly associated it with Onega Distant, 1908, after examining a photograph of the type of $A$. bipunctata.

\section{Aglaenita bipunctata Spinola, 1850}

Figs $1-13$

Aglenita [sic] bipunctata Spinola, 1850: 134. - Evans, 1947: 251. - Metcalf, 1966: 233.

Aglaenita bipunctata; Young, 1977: 286.

Specimens examined. Sintype female of Aglenita bipunctata Spinola deposited in the Museo Regionale de Scienze Naturalli de Torino, Italy, with follow labels: Spinola/Brésil/Cayenne/Buquet. 


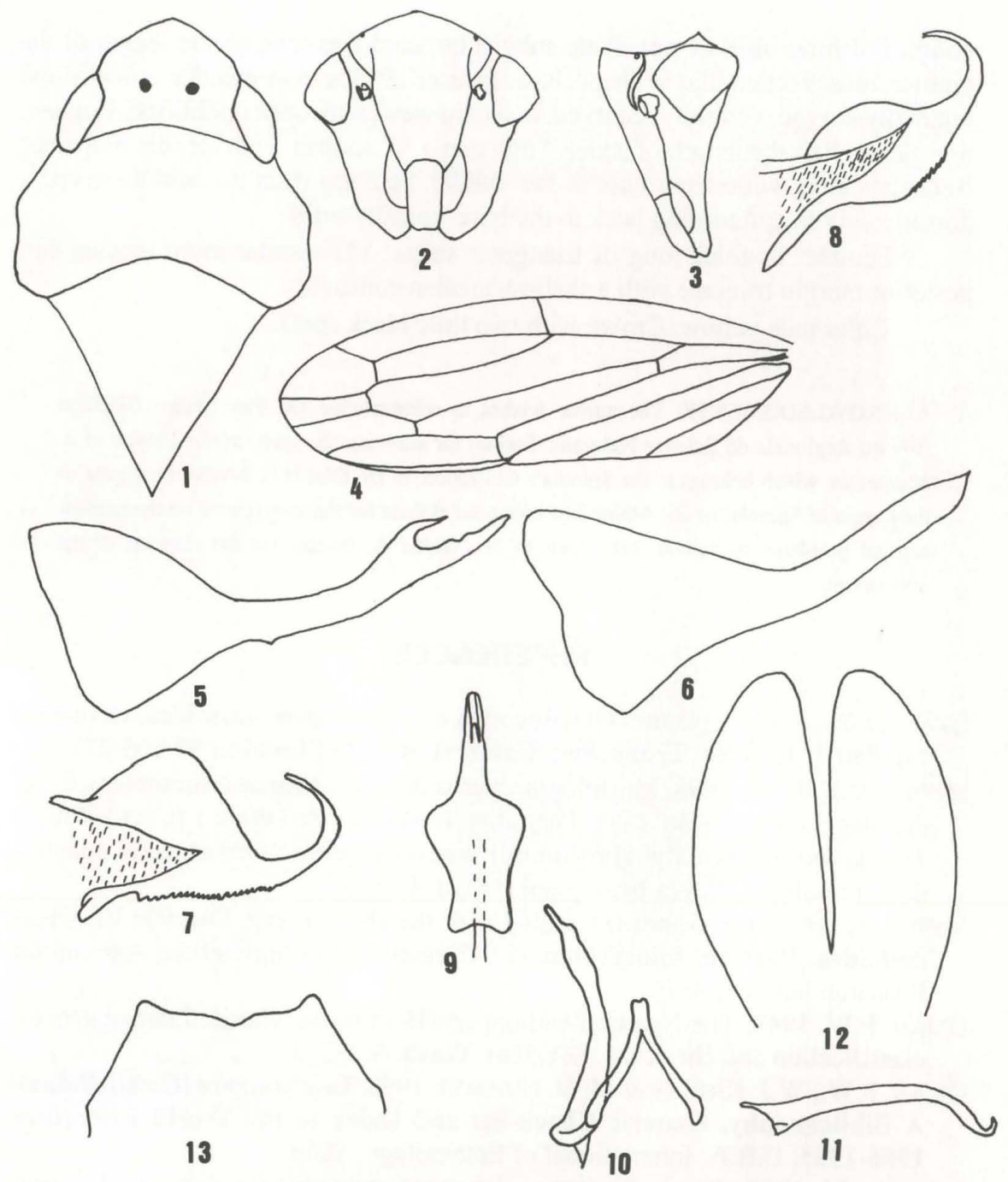

Figs 1-13. Aglaenita bupunctata. (1) Head, pronotum e scutellum, dorsal view; (2) head, antero-ventral view; (3) head, lateral view; (4) tegmine, lateral view; (5-6) pygofer, lateral view; (7-8) aedeagus, lateral view; (9) aedeagus, in dorsalview; (10) style and connective, dorsal view; (11) style, lateral view; (12) plate subgenital, ventral view; (13) sternite VII of female, ventral view.

BraziL, Mato Grosso: Sinop, 5 males and 4 females, 1974, M. Alvarenga leg.

Measurements (mm). Males/female: 10,17/12,67. Structural characters as in generic description. Pygofer of the male basally wide with strong medium narrowing in direction to ventral margin, forming a projection longer than the basal 
width, finishing bifid or not. Plate subgenital almost as long as the length of the pigofer, more rectangular in shape, basally fused. Styles long, slender, apically and internally curved, ventrally recurved, in lateral view, with apex unciforme. Connective almost half the length of styles, "inverted - V" shaped, with slender branches. Aedeagus long, wide from base to the middle, tapering from the middle to apex, dorsally curved and turning back to the base, apically bifid.

Female. Pygofer long of triangular shape. VII sternite more rectangular, posterior margin truncate with a shallow median concavity.

Color pale yellow. Crown with two little black spots.

ACKNOWLEDGMENTS. The author wishes to acknowledge Dr. Pier Mauro Giachino (Museo Regionale de Scienze Naturalli, Torino) for allowing the study of the sintype of $A$. bipunctata, which belongs to the Spinola's Collection; to Dr. Olaf H.H. Mielke for copies of the papers of Spinola; to Dr. Albino Morimasa Sakakibara for the suggestions on the nomenclatural problems treated in this paper; to Dr. Walter A. Boeger for the revision of the manuscript.

\section{REFERENCES}

Evans, J.W. 1947. A Natural Classification of leaf-hoppers (Jassoidea, Homoptera). Part 3: Jassidae. Trans. Soc. Entomol. Royal of London 98:105-271.

MEJDALANI, G.L.F. 1998. Morfologia externa dos Cicadellinae (Homoptera, Cicadellidae): comparação entre Versigonalia rufucauda (Walk.) (Cicadellini) e Tretogonia cribrata Mel. (Proconiini), com notas sobre outras espécies e análise da terminologia. Revta bras. Zool. 15 (2): 451-544.

Metcalf, Z.P. 1966. General Catalogue of the Homoptera. Fascicle VI. Cicadelloidea. Part 16. Idiocerinae. U.S. Department of agriculture, Agriculture Research Service, 237p.

OMAN, P.W. 1949. The Neartic Leafhoppers (Homoptera: Cicadellidae) a generic classification and check list. Soc. Ent. Wash. 3: 1-253.

OMAN, P.W.; W.J. KNIGHT \& M.W. NIELSON. 1990. Leafhoppers (Cicadellidae). A Bibliography. Generic Check-list and Index to the World Literature 1956-1985. C.B.A. International of Entomology, 386p.

SpINOLA, M. 1850. Tavola Sinopttica dei generi spettanti alla classe degli insetti artroidignati, Hemiptera, Linn. Latr.,-Rhyngota, Fab,-Rhynchota, Burm. Mem. Mat. Fis. Soc. Ital. Sc. Modena 25: 43-100.

1850. Di algunci generi d'insetti artroidignati nuovamente proposti dal socio attuale Signor Marchese Massimiliano Spinola nella sua tavola sinottica di questo ordine che precede la presente memoria. Mem. Mat. Fis. Soc. Ital. Sc. Modena 25 (1): 101-178.

YounG, D.A. 1977. Taxonomic study of the Cicadellinae (Homoptera: Cicadellidae). Part 2. New World Cicadellini and the genus Cicadella. Bull. N. Carol. agric. Exp. Stn 239: VI+1135p.

Recebido em 25.IV.1997; aceito em 25.III.1999. 